\title{
The Indelible Challenges of Student Retention in Higher Education: Imperatives for a Closer Scrutiny
}

Wondwosen Tamrat ( $\nabla$ wondwosentamrat@gmail.com )

St. Mary's University https://orcid.org/0000-0002-2688-8744

Research Article

Keywords: student attrition, student retention, student drop-out, student persistence, Ethiopian higher education

Posted Date: January 29th, 2021

DOI: https://doi.org/10.21203/rs.3.rs-162412/v1

License: (c) This work is licensed under a Creative Commons Attribution 4.0 International License. Read Full License 


\section{Abstract}

Student attrition remains a serious challenge for universities across the globe despite the extended attention it continues to attract. Given the meagre research available in the Global South and particularly in Africa, this study was conducted to assess the status of student attrition in 15 Ethiopian public universities. The study examined the scope, nature and causes of student attrition at the level of institutions, programs and gender wise. The findings revealed that the attrition rate at Ethiopian public universities manifests a high level of waste that goes against the national ambition of expanding higher education through wider participation and student success. Universities were also found deficient in terms of tracking the progress of their students, hampering their potential for follow up and early interventions. It is argued that closer scrutiny and robust responses are needed both at policy and institutional levels in order to bring about the improvements sought.

\section{Background}

The retention of students in higher education institutions has been a topic of interest since the establishment of formal education systems (Aljahani, 2016). Owing to its multifaceted implications, the issue of student retention continues to draw significant attention across the globe not only from institutions but also from governments that seek to incorporate it as part of their policy directions, strategic considerations and overall student service operations (Beer \& Lawson, 2016; Crosling, 2017; Crosling et al., 2009; Lang, 2001; Levitz \& Noel, 2008). However, despite its importance, student retention still remains a serious and costly challenge for higher education institutions as the level of attrition observed across many systems and institutions show little changes (Beer \& Lawson, 2016; Blackori, 2019; Bokana, 2010; New Vision, 2019; Demetriou \& Sciborski, 2011; Thomas \& Quinn, 2003).

In Ethiopia, student retention assumes a high level of importance within the education sector due to its critical role in meeting national goals and institutional objectives. The various national policies adopted identify the development of human capital as a key strategic tool for poverty reduction, economic development and meeting Ethiopia's aspiration of becoming a middle-income country by 2025 (Ministry of Education [MoE], 2015; Ministry of Finance and Economic Development [MoFED], 2016). Pragmatic considerations related to the surge of student number at the lower levels of education also compel any similar system to expand at a rate which can modestly-if not fully- address the needs of the desired percentage of pupils that complete secondary education. Currently, there are more than thirty million students enrolled at 34000 institutions of primary to secondary education (MoE, 2017). Not less than $20 \%$ of those who complete secondary schools are expected to join higher education institutions that must, as a matter of necessity, grow to accommodate the burgeoning demands for university education.

However, as much as the continued growth of the sector to respond to this growing need has been hailed as a remarkable achievement in a country whose education system had slumbered for many years, there have equally been arguments against the current 'unbridled' growth whose negative consequences are yet to be 'reaped' in the future. A notable example is Negash's characterization of the current trajectory as an inimical move traversing 'from crisis to the brink of collapse' (Negash, 2006). It is interesting to note that within the wider debate about Ethiopia's higher education expansion one element that is consistently missing is how much what has been achieved in terms of access has been translated into success. Despite being identified as one of the most widely studied areas of higher education spanning more than four decades of research interest in other parts of the globe (Tight, 2019; Tinto, 2006), commensurate with the situation in most developing countries, there is very little research in the Ethiopian context that offers a comprehensive picture about student progression and retention. Neglecting such a significant issue cannot be tenable in the context of national policies and institutional priorities that aim at promoting wider participation and gender parity across the whole system. This study was driven by the need for addressing this research gap.

The paper is structured in four parts. The first part offers the theoretical foundations of student retention followed by the research context, the research design and major findings, and conclusions of the study.

\section{Student Retention: Theoretical Underpinnings}

Despite having a long history dating back to the establishment of educational institutions, the issue of student retention at universities is often regarded more of a $20^{\text {th }}$ century phenomenon. While the focus before the $19^{\text {th }}$ century had been more on student survival (Aljahani, 2016; Demetriou \& Sciborski, 2011), a strengthened conceptual evolution of student retention started to emerge after a change of the 'survival' outlook and with the steady growth of higher education over the next century. Student attrition particularly started attracting scholarly attention in the 1930s, albeit research in the area only began to take a more solid shape after the second world war and especially during the 1960 s which were marked by the growth of students entering post- secondary institutions (Burke, 2019; Demetriou \& Sciborski, 2011; Levitz \& Noel, 2008; Tight, 2019).

While the subject continued to assume prominence in the ensuing decades, student retention and its multiple manifestations were interpreted differently at different times. At first, student retention was understood as a psychological construct exclusively influenced by individual attributes, skills and motivation with little or no linkage with what goes within institutions or their environment (Aljohani, 2016; Burke, 2019; Kerby, 2015; Tinto, 2006). This traditional conceptualization of 'student mortality' and emphasis on investigating students' failure (as opposed 
to their success) changed in the 1970s with the arrival of new research that began to explain the effects of retention on students from various backgrounds and institutional settings. Over the years, the task of addressing student attrition has significantly moved from being the responsibility of individual students to that of institutions and relevant stakeholders (Burke, 2019; Crosling, 2017). A wide array of theories and different perspectives that explain student attrition and mechanisms of retention have been proposed since then.

One of the major reasons that attracts special attention towards student retention is the level of attrition experienced in many systems and geographical locations, and the implications thereof. Studies in the USA, for instance, indicate that for the last one hundred years only $50 \%$ of those who joined higher education institutions managed to complete their studies (Demetriou \& Sciborski, 2011). According to Thomas \& Quinn (2003) attrition of higher education students is estimated at $20 \%$ in the Netherlands and $26 \%$ in Sweden, while in Canada $25 \%$ of full-time students and $59 \%$ of part-timers do not complete their courses. The situation appears to be worse in the Global South. Despite the limited studies undertaken across the continent, the attrition rate at most African universities is said to be not less than $50 \%$ which is worrisome considering the fact that only a limited percentage of the relevant age cohort in the continent have access to tertiary education. In South Africa, for instance, less than $15 \%$ of the relevant age cohort have access to higher education but about $50 \%$ of students drop out of university in their first year and a mere $15 \%$ of them complete their degrees in the allotted time (Bokana, 2010). A study in Uganda shows that almost $30 \%$ of all students who join university education on various degree programs never finish their courses on time, or just drop out (New Vision, 2019).

Over the last few decades, the global concern about attrition has continued triggered by the expansion of higher education and its resultant effects on post-secondary and higher education, increased diversity in the demographics and background of students, and a strengthened focus on the quality, impact and outcomes of higher education systems (Burke, 2019; Cook, 2007; Crosling, 2017). Apart from its role in educational participation, the moral and civil right issues of disadvantaged students, financial implications on a country's education system, and the increasing demand for accountability of higher education institutions have been a further impetus to the increasing concern about student retention (Beer \& Lawson, 2016; Crosling, 2017; Crosling et al., 2009; Levitz \& Noel, 2008). Indeed, given its multifaceted implications and undesirable effects, it is no surprise that the issue of student retention continues to attract significant attention not only from students and their families but from governments, policy makers, tax payers and accreditation agencies (Crosling et al., 2009; Levitz \& Noel, 2008). Many governments are now providing more attention to the issue, taking specific measures like enforcing statistical documentation on attrition and taking retention as a measure of institutional success to be rewarded through policy instruments (Crosling et al., 2009; Rowley, 2003). The issue is also drawing increasing attention from institutions themselves that are actively involved in incorporating student retention as part of their policy directions, strategic areas and overall student service operations they undertake (Beer \& Lawson, 2016; Lang, 2001).

\section{Reasons for Non-completion}

Student attrition is most often regarded as a complex and intractable problem caused by multifarious causes (Beer \& Lawson, 2016; Cook, 2007). The reasons that force university students to discontinue their studies are varied, complex and can be affected by specific contexts and the nature of particular institutions. Cook (2007) classifies these reasons into causes that pre-date university entry and those that occur after entry. Reasons such as academic under-preparedness, managing the transition to university, long-term goals and problems with expectations are all experienced before entry. Among the variety of reasons posited to account for student dropout are: individual characteristics, student integration and the characteristics of a given institution itself; weak institutional and/or course match; unsatisfactory academic experience; lack of social integration; financial issues; and personal circumstances (Cook, 2007; Crosling, 2017; Tinto, 1975, 2006). The family background of the student, his/her individual characteristics/ability, unsatisfactory past educational experiences, poor preparation for higher education, personal circumstances, and students' goal commitment constitute individual characteristics (Fowler, n.d.; Jensen, 2011; Tinto, 1975, 2006). In addition to individual characteristics, the longitudinal interaction between individual students and their institution in their academic integration process (e.g. grade performance and intellectual development), social integration (peer group associations, semi- formal extracurricular activities), interaction with faculty and administrative personnel are considered to be important factors in retaining students. Student attrition is also affected by the characteristics of a given institution- its resources, facilities, structural arrangements and composition of its members (Jensen, 2011; Tinto, 1975, 2006).

\section{Institutional Responses to Student Attrition}

In addition to introducing appropriate policies and practices that promote academic goals and provide empirical evidence of student success, higher education institutions are expected to alter the nature of student experiences, improve the overall character of colleges, and address the deeper roots of student attrition (Beer \& Lawson, 2016; Crosling, 2017; Tinto, 1999). However, despite attracting wider interests across countries and institutions in diverse contexts, it appears that the corresponding attention paid to improving the status-quo remains still meager. Caruth (2018, p. 17) notes, "Despite the attention given to student retention for nearly half a century, college graduation and persistence rates have not improved in over two decades. Furthermore, time to degree rates suggest that it is taking more time to earn degrees." As noted by Simpson and Johnston (2006), institutional responses have been one of pure neglect or limited attention. Even where support is made available, it has been usually limited, piecemeal and highly segmented. Simpson aptly captures the ambivalence within the higher education sector in the following words: 
Higher education is a strange business. No other form of manufacturing would take in tested components (new students) and produce a final product (graduates) with a wastage rate of $20 \%$ or more. Or at least if such a business existed then it would very rapidly go bankrupt. Yet universities not only largely ignore such waste but even appear to take a perverse pride in it, maintaining that it indicates high academic standards (2005, P. 34).

In order to alleviate this challenge, more emphasis is suggested to be given toward addressing systematically obstacles of college completion (Crosling, 2017; Jensen, 2011; Keber, 2015; Tight, 2019; Tinto, 2007). Institutions are advised to change their overall character, alter the prevailing nature of student educational experiences, and addres the deeper roots of student persistence (Tinto, 2006). Prominent among suggested strategies have been setting student expectations, providing the needed academic, financial, social, and personal support, assessment and feedback, and student involvement or engagement (Tinto, 1987, 1999, 2006). Against the above backdrop this study seeks to examine the nature of student attrition, its causes, and the measures taken to combat attrition in the Ethiopian academic set up.

\section{The Research Context}

The expansion of higher education in Ethiopia over the last two decades remains one of the most glaring achievements of the sector towering over other aspects of policy debates and public discourse. Though the first higher education institution was established in 1950, the Ethiopian higher education sector remained elitist in its orientation until the end of the 1990s both in the number of higher education institutions established and the corresponding rate of access created. The last few decades have, however, seen a significant 'massification' of the sector driven by new policy directions that enhanced the expansion of the public system and the birth of private higher education institutions (PHEls) that were alien to the system (Author, 2008). A sector that had only two universities, 17 colleges and around 37,000 students (World Bank, 2003) at the turn of the millennium has exponentially grown to accommodate a million students, 50 universities, and over 260 private higher education institutions. Despite starting very low even by Sub-Saharan standards, the country has now attained a Gross Enrollment Rate of over 12 percent which has for the first time surpassed the regional average of 8 percent (MoE, 2018). This pattern is set to continue in the future having been necessitated by the prevailing national policies and pragmatic considerations across the education sector.

Since the early days of the sector's history, student retention has been a pervasive problem of the Ethiopian higher education system. The dropout rates at Addis Ababa University- the nation's premier institution-from 1950 until the mid-sixties was around 40 \% (Wagaw, 1990). There were a variety of academic and non- academic reasons such as lack of appropriate orientation and counselling, lack of sound academic preparation at high school, forced choice of fields of studies, poor language skills, the need to support families that mainly accounted for student attrition. The extent of the problem was so big that in 1969 the university administration had to set up a specific Freshman Program with separate administrative unit in order to counter the challenges by developing student skills in language, conceptualization and reasoning and improve performance and efficiency within the university (Wagaw, 1990, p159). This initial arrangement did not, however, immediately alter the rate of attrition at the universities. The attrition rate went down rather significantly in 1985/86 after a new arrangement of supplemental examination- a scheme of repeat examination given during vacation time to enable low achievers get promoted to the next class- went into effect in 1984/85 (UNESCO, 1988). This arrangement continued to work until it was abandoned in the mid-1990s- the time when the higher education sector embarked on unprecedented scheme of expansion.

Policy directions and education sector plans set over the last few decades emphasize the need for enhancing access and success in the Ethiopian higher education sector (MoE, 2015). However, while the quantitative achievements of the higher education sector over the last two decades are clear, little is known about the rate of student success, except for few studies that investigated the rate and causes of attrition at particular universities and programs. The major challenge in this area has been the paucity of national and institutional data across the sector and within individual institutions of higher learning. The only available national data-the Annual Education Statistics Abstract published by the Ministry of Education- offers the most comprehensive information on the number of admitted students and graduates at a national level but fails to incorporate retention and completion rates across the system. Obtaining data from individual institutions is not also easy owing to poor systems of documentation and knowledge about the progress of their students (Author, 2018). This deficiency has been partly offset by the publication since 2008 of quality audit reports of Ethiopian universities undertaken by Higher Education and Relevance Agency (HERQA). The bulk of information used in this study was drawn from this available national corpus data.

\section{Purpose of the Study}

This study seeks to identify the nature of student attrition in the Ethiopian context by examining the rate of student progress, causes of attrition, practices in the documentation of student attrition, and the measures taken to combat current challenges using a huge set of data produced by the national Higher Education Relevance and Quality Agency (HERQA).

\section{Method}


The study adopts a qualitative methodology and uses document analysis as a major means of data collection. The use of document analysis as a research methodology provides not only the needed research data on a given subject but also information and insights that can be valuable in creating a knowledge base (Bowen, 2009). As noted earlier, the data used in this study were drawn from the quality audit reports of 15 public universities generated by HERQA. The quality audit reports span the academic years of 2007/08 through 2017, covering a period of over 10 years. The choice for public institutions was purposive because the sector caters to 86 percent of higher education enrollment in the country (MoE, 2017) and can offer a comprehensive picture of the student retention phenomenon across the sector and at a national level.

The specific sections of the quality audit reports related to student progression were carefully extracted to serve as major sources of information. Previous research on the subject and documentary evidence on policy directions and institutional practices were also gathered to triangulate data obtained from the quality audit reports.

\section{Findings And Discussion}

The analytic procedures followed in this study involved finding, selecting, appraising (making sense of), and synthesizing data contained in the quality audit reports examined (Bowen, 2009). The document analysis finally yielded four major areas that manifest the state of student attrition in the sample universities: documentation practices, scope of student attrition, causes of student attrition, and institutional measures taken to combat attrition. The remainder sections of the paper focus on these areas, followed by the conclusion of the study.

\section{Documentation of student progression}

The importance of data management and reporting is emphasized in Ethiopia's 2019 higher education proclamation which stipulates the duties of higher education institutions regarding organizing and using institutional information and making available such information to internal and external users. Accordingly, all institutions are required to establish efficient systems for statistical data collection and information exchange among themselves, their units and with the Ministry of Education (now Ministry of Science and Higher Education) to which they are accountable. Higher learning institutions are expected to gather and document all the necessary information on student progression, the level of students' attrition, reasons for dropouts and the measures/actions taken to minimize attrition rates (HERQA, 2008a). However, one consistent observation about most of the sample universities considered in this study is their deficiency in terms of the systematic gathering of student data and their poor knowledge about their own students' progression and retention.

Most institutions do not produce reliable data on attrition and retention due to limited sources of information, lack of organized reports, inaccuracies, poor mechanisms of calculating attrition, which are symptomatic of a weak information system. The following observation was made about one of the universities:

The EQA [External Quality Audit] team observed that data were not collected on a routine/regular basis so that the numbers of students progressing from initial registration to graduation on each program could be tracked semester by semester and year by year basis. Since there were no records on the attrition of students from cohorts following a particular program, the EQA team was not able to give detailed attrition and progression of students (HERQA, 2014, p. 49).

Arguably, the lack of a well-organized information system to capture data on student retention can have serious impacts on the planning, monitoring and appraising of student progress including challenges in making informed, timely and reliable decisions (Author, 2018).

The quality audit reports of most of the universities also show that the concept of attrition was understood differently. This is evidenced by the fact that the data offered by universities were often questioned by HERQA's quality auditors who consistently recalculated figures and commented that the reality on the ground may be more exacerbated than what the data might reveal. This serious gap is both an indication of the system's current deficiency in establishing consistent understanding about the concept of retention across institutions and the little attention given by universities themselves to such an important matter of concern. The negative impact of this negligence on day-to-day operations and interventions at institutional and/or national level can be easily predicted.

It is worthy of note that despite the difference in terms of the respective time the audits were undertaken between the older (2007/8) and the other relatively young universities (2017), there does not seem to be any substantial variation among institutions as related to the practice of documentation, reporting accurate retention and progression figures, and moving towards a similar definition of the concept of retention. This is again suggestive of the meagre attention the issue has received in terms of mitigating challenges both at system and institutional levels. The findings discussed below further corroborate this observation.

\section{Scope of student attrition}

In most cases, the rate of student attrition found across universities exhibits not only an unnecessary wastage that implies the possible loss to individual students, institutions and the country at large but it also implies a direction against the plans and aspirations set by universities and 
policy makers. Table 1 below offers a sample of institutional level attrition rate based on the information obtained from universities where data were available.

\section{Table 1}

\section{Student Attrition at Institutional Level}

\begin{tabular}{|l|l|}
\hline Sample University & Rate of Attrition (\%) \\
\hline Adigrat University & 50 \\
\hline Arbaminch University & 50 \\
\hline Adama University & 18 \\
\hline Bahirdar University & 29 \\
\hline Hawassa University & 12 \\
\hline Jimma University & 24 \\
\hline Mekelle University & 37 \\
\hline Mizan Tepi & 30 \\
\hline Average & 35.7 \\
\hline
\end{tabular}

\section{Source: Author Compilation from Institutional Quality Audit Reports}

On average, the seven universities about which data were obtained lost $36 \%$ of their students before graduation. The situation is particularly worse in Arbaminch University and Adigrat University (relatively a new institution) where half of their students were lost from a single cohort. The major stage at which this amount of loss occurs is during the transition period from freshman to second year. For instance, a close examination of the quality audit report of Hawassa University (HERQA, 2008a) indicated that while an overall attrition rate of $12 \%$ was recorded at an institutional level, the attrition rate for freshman students was well over $30 \%$. This highlights the urgent need for giving special attention to the freshman level where changes in expectations and aspirations, social and cultural environments, institutional laws and regulations, and learning style pose a serious challenge for the majority of students (Kassie, 2018; Molla \& Cuthbert, 2014).

On a positive note, there are a few universities like Wolaita Sodo where the institutional attrition rate appears to be going down. However, the reasons that account for this improvement are not clear given the contrasting views among the university community itself as to what explains the change. The following observation from HERQA auditors is quite instructive:

According to some of the informants, this was achieved because of support services provided for students such as learning materials and financial supports for those with economic problems. Some other informants have a different view for the decrease in the attrition rate. According to them, the reduction in attrition rate is due to leniency in grading; and [they] forwarded their view that this has to be done without comprising the quality of education (HERQA, 2017).

A further examination into the nature of attrition at program level revealed additional facts. The data do not indicvate a clear pattern across universities as regards the attrition trend at specific departments, but the rate in some programs is outrageously high.

\section{Table 2}

\section{Student attrition at program level}




\begin{tabular}{|l|l|l|}
\hline Sample University & Department/Faculty & Attrition rate(\%) \\
\hline Debremarkos & Mathematics & 50 \\
\hline Debre Birhan & Mathematics & 31 \\
\hline & Psychology & 35 \\
\hline & Economics & 45 \\
\hline Haramaya & Business and Economics & 37 \\
\hline & Education & 27.5 \\
\hline Gondar & Management and Economics & 29 \\
\hline & Social Science and Humanity & 38 \\
\hline Mizan Tepi & Health sciences Average & 32.5 \\
\hline Jigjiga & Social science and humanities & 17.5 \\
\hline \multicolumn{2}{|c}{ A } \\
\hline
\end{tabular}

\section{Source: Author Compilation from Institutional Quality Audit Reports}

An average attrition rate of $36 \%$ was recorded in the various departments of the universities. This is comparable to the overall attrition rate calculated at institutional level. Despite the lack of a consistent pattern in the data in terms of which programs experience attrition most, the rate of attrition for the sciences appears to be higher than the rate for social science and humanities.

\section{Female attrition rates}

When it comes to the retention and progress of female students, an alarming rate of loss is consistently observed across all universities.

Table 3

Female students' attrition at institutional level

\begin{tabular}{|l|l|}
\hline Sample University & Attrition Rate (\%) \\
\hline Adama & 58 \\
\hline Bahirdar & 50 \\
\hline Debrebirhan & 38 \\
\hline Mekele & 64 \\
\hline Wolaita Sodo & 45 \\
\hline Average & 51 \\
\hline
\end{tabular}

\section{Source: Author Compilation from Institutional Quality Audit Reports}

As may be seen in the table, more than half of female students enrolled in most universities do not progress to the final year. The rate at which universities lose female students is disproportionately higher than the attrition rate at institutional level. For instance, in Mekele, where the average attrition rate for female students was $64 \%$, the overall average attrition rate for regular students was 37\% (HERQA, 2008b). Even in recently established universities such as Wolaita Sodo, the dropout rate for female students was $45 \%$ while the withdrawal ratio rose to $54.4 \%$ (HERQA, 2014). In a similar vein, the average attrition of females was more than twice that of males (HERQA, 2008b). This is a consistent manifestation of the Ethiopian education system in which girls are underrepresented and underperform due to a multitude of social, economic and institutional factors that affect their progression and graduation (Author, 2019; Kassie, 2018; Molla \& Cuthbert, 2014).

\section{Table 4}

Female students' attrition at program level 


\begin{tabular}{|c|l|c|c|}
\hline $\begin{array}{l}\text { Sample } \\
\text { university }\end{array}$ & Department/Faculty & $\begin{array}{l}\text { Overall attrition rate at } \\
\text { department level (\%) }\end{array}$ & $\begin{array}{l}\text { Female only attrition rate at } \\
\text { department level (\%) }\end{array}$ \\
\hline Gondar & Management and Economics & $22-36$ & $40-63$ \\
\hline & Medicine and Health Sciences & NA & 50 \\
\hline & Social Science and Humanity & $25-51$ & $53-70$ \\
\hline & Applied Natural Science & NA & $51-72$ \\
\hline Haramaya & Business and Economics & 37 & 59.3 \\
\hline & Education & 27.5 & 56 \\
\hline Hawassa & Agriculture, Natural Science, & NA & Over 50 \\
& Social Studies & NA & 25 \\
\hline & Veterinary Science & & \multicolumn{2}{|c|}{} \\
\hline
\end{tabular}

\section{NA $=$ Not Available}

\section{Source: Author Compilation from Institutional Quality Audit Reports}

It can be seen that the rate of attrition for female students at the level of programs is similarly higher than that of male students- in most cases double the overall attrition rate at departmental level. This corroborates with other local studies where the rate of attrition for female students consistently outstripped that of male students (Dagnew \& Danlena, 1995; Kassie, 2018; Molla \& Cuthbert, 2014; Tilahun, 2003; Weldegiorgis \& Awel, 2013). The finding is a clear indication that government policies that promote improved female representation in Ethiopian tertiary institutions are far from being met, hindering improvements sought in this area (Author, 2017, 2019). A system that loses as many as half of its female students cannot claim to be championing gender parity nor can it be able to bridge this gap in the shortest time possible.

The data examined so far in general indicate that the overall attrition rate experienced at the levels of institutions, programs and gender- wise is counter to what is envisaged to be attained at national level. For instance, by the end of 2020, the Education Sector Development Program V (MoE, 2015) aimed at increasing participation and success of female students; raise the completion rate of first year undergraduate to $95 \%$ and graduation rate of undergraduates to $70 \%$ but all of these are very unlikely to be achieved.

\section{Causes and measures taken to combat attrition}

As revealed from the corpus data, the major reasons that explain student attrition at Ethiopian universities can be classified into personal, institutional and social factors. The following table shows the reasons identified as causes of attrition at the universities.

\section{Table 5}

\section{Reasons for Attrition and Non- completion}




\begin{tabular}{|c|c|c|}
\hline Category of reasons & Specifics & $\begin{array}{l}\text { Sample } \\
\text { university }\end{array}$ \\
\hline Academic & $\begin{array}{l}\text { Poor preparation, poor academic background, law academic achievement, } \\
\text { academic failure, heavy workload due to make up classes }\end{array}$ & \begin{tabular}{|l} 
Adama \\
Haramaya \\
Hawassa, \\
Mekele, \\
Debrebirhan \\
Debremarkos \\
Wolaita Sodo
\end{tabular} \\
\hline $\begin{array}{l}\text { Institutional resources } \\
\text { and support }\end{array}$ & $\begin{array}{l}\text { Lack of advice and tutorials, poor affirmative action support, lack of academic } \\
\text { advice, lack of continuous assessment, shortage of reference materials, limited } \\
\text { internet access }\end{array}$ & $\begin{array}{l}\text { Haramaya } \\
\text { Hawassa } \\
\text { Debremarkos } \\
\text { Wolaita Sodo }\end{array}$ \\
\hline Personal problems & $\begin{array}{l}\text { Ill health, financial problems, legal problems, personal conflict, language } \\
\text { problems, socializing problems }\end{array}$ & $\begin{array}{l}\text { Adama } \\
\text { Haramaya } \\
\text { Hawassa } \\
\text { Mekele } \\
\text { Debrebirhan } \\
\text { Debremarkos } \\
\text { Wollo }\end{array}$ \\
\hline $\begin{array}{l}\text { Reasons not identified } \\
\text { due to poor } \\
\text { documentation/ record }\end{array}$ & & $\begin{array}{l}\text { Arbaminch } \\
\text { Bahir Dar } \\
\text { Gondar } \\
\text { Jimma } \\
\text { Dilla }\end{array}$ \\
\hline
\end{tabular}

\section{Source: Author Compilation from HERQA's Institutional Quality Audit Reports}

The particular reasons that account for student attrition were numerous but mainly pertained to poor academic background, health and family problems, lack of sufficient and consistent academic advice and tutorial support, language problems, access to sufficient resources, and student heavy workload. Some of these reasons go beyond personal factors often identified as lack of time management, carelessness, tension, fear of failure and lack of adequate effort were reported as the major factors that threatened or encountered students' academic performance (Sewasew, 2014). The findings are rather indicative of the complex nature of the causes and possible variations among institutions, more consistent with studies that highlighted the multifarious nature of student attrition (Aljohani, 2016; Beer \& Lawson, 2016; Bokana, 2010; Burke, 2019; Kassie, 2018; Molla \& Cuthbert, 2014).

It should also be noted that five institutions were not able to identify the cause of students' attrition due to poor record systems. Arguably, this suggests that despite the poor rates of attrition universities are widely experiencing, commensurate efforts are not made to curb the existing loss of students (Beer \& Lawson, 2016; Tinto, 2006). HERQA's audit reports consistently indicate that even where there are claims by institutional authorities in terms of exerting specific efforts to improve retention, they have in most cases been refuted by students who attested that such efforts do not exist; and if at all they exist, they are cosmetic, disorganized and not sustainable.

\section{Conclusion}

Obviously, higher education has the potential to enhance significant gains at the level of individuals, the wider economy and the society at large. The benefits of increased college completion towards betterment of the individual, economic growth and productivity is well- established (Tinto, 2004). That is why countries like Ethiopia have made the issue of human resource development the core segment of their national plans, comprising the achievement of broader goals like economic development and poverty reduction (MoE, 2015; MoFED, 2016). However, this study 
revealed that with very few exceptions, the majority of the sample universities do not have a well-organized system that provides reliable data on student progression and completion. Owing partly to the lack of definition, there is wide variation among institutions in terms of understanding and computing appropriate statistics on the subject. This problem is compounded by the lack of institutional and national policies and strategies that address the issue in a coherent manner (Author, 2018).

A related finding is the limited efforts universities are making toward addressing the learning needs of their students despite its direct implication for student retention. As noted by Caruth (2018), institutions have the duty to make postsecondary education a successful experience for students to be able to do well, to graduate, and to fulfil their wishes in life. Improving the existing institutional deficiencies in Ethiopian universities requires identifying influences and causes of student attrition so that necessary measures could be taken towards improving student persistence and graduation which should eventually accrue not only to individual students but also to families, the society and the nation at large. This is without forgetting the need for giving special attention to disadvantaged groups like female students whose attrition rate is unacceptably high. This should not, however, preclude the role of students who must share responsibility for adjustment and contribution to the improvement of their own academic experience and retention (Crosling, 2017).

The findings of this study further suggest that although much has been said about the expansion of higher education and the gains in terms of access, very little attention has been paid in the system to the rate of student progression and completion. In terms of the wider discourse, it rather appears that access and completion rates are treated as if they were incongruent constructs of the system with the latter little discussed as compared to the former, notwithstanding the need for treating it as a critical component of the expansion drive. Any discussion on the rate of access to higher education in Ethiopia- about which much continues to be said- will remain a story with only its first part told unless it is followed by sufficient expose of the rate of student completion rates and the causes thereof.

The foregoing suggests the urgent need for greater understanding of the phenomenon and improving the rate of student retention at Ethiopian universities. It is high time that the system begins to examine how claims made about the expansion of the higher education sector are fraught with serious gaps due to the indelible challenges of student attrition that should be addressed through a combination of comprehensive policies, strategies and systems designed and implemented both at national and institutional level. In this regard, the need to alter the overall character of universities, the prevailing nature of student educational experiences, and the commitment to address the deeper roots of student persistence (Crosling, 2017; Tinto, 2006) remain more pressing than ever when the country is poised to augment the scale of its higher education expansion further.

As noted by Beer \& Lawson (2016) the re-conceptualizing of attrition as a wicked problem requires adopting agile strategies that are based on lessons from previous deficiencies. There may be no easy or quick answer to the myriad and complex challenges of student retention since the interconnected and contextually dependent array of factors that contribute to success may preclude one-shot solutions (Beer \& Lawson, 2016). However, research indicates that it is possible to curb attrition through proper government policies and concerted institutional efforts that consider retention as part of the strategic planning, mission actions, or key performance indicator of institutional quality (Beer \& Lawson, 2016; Blackori, 2019; Crosling et al., 2009; Kerby, 2015; Tinto, 2004).

In addition to tackling the issue of attrition in a comprehensive manner, Ethiopian universities should shore up their information gathering and processing capabilities on student retention on a consistent basis. On the part of the Ministry of Science and Higher Education, more needs to be done toward the development of accurate, efficient and integrated higher education information management systems without necessarily impinging on the diversity of institutions and institutional missions (Tinto, 2004). Further, the Ministry is expected to ensure that national goals set as regards student success are properly pursued and managed at institutional level.

\section{Declarations}

Competing interests: The author declares no competing interests.

\section{References}

Aljohani, O. (2016). A review of the contemporary international literature on student retention in higher education. International Journal of Education and Literacy Studies, 4(1), 40-52.

Author. (2008).

Author. (2017).

Author (2018).

Author. (2019). 
Beer, C., \& Lawson, C. (2016). The problem of student attrition in higher education: An alternative perspective. Journal of Further and Higher Education. Advance online publication. https://doi.org/10.1080/0309877X.2016.1177171

Blakcori, N. (2019). Recruitment and retention of students in developing countries: An overview. Professors without

borders. https://www.researchgate.net/publication/337215235_Recruitment_and_Retention_of_Students_in_Developing_Countries_An_Overview

Bokana, K. G. (2010). The attrition crisis in South African universities. How to keep students on the graduation path. Journal of Interdisciplinary Economics, 22(3), 181-201. https://doi.org/10.1177/02601079X10002200302

Bowen, G. (2009). Document Analysis as a Qualitative Research Method. Qualitative Research Journal, 9(2), 27-

40. https://doi.org/10.3316/QRJ0902027

Burke, A. (2019). Student retention models in higher education: A literature review. College and University, 94(2), 12-22.

Caruth, G. D. (2018). Student engagement, retention, and motivation: Assessing academic success in today's college students. Participatory Educational Research, 5(1), 17-30. https://doi.org/10.17275/per.18.4.5.1

Crosling, G. L. (2017). Student retention in higher education, A shared issue. In J. C. Shin \& P. Teixeira (Eds.), Encyclopedia of international higher education systems and institutions (pp. 1-6)., https://doi.org/10.1007/978-94-017-9553-1_314-1

Crosling, G., Heagney, M., \& Thomas, L. (2009). Improving student retention in higher education: Improving teaching and learning. Australian Universities Review, 51(2), 9-18.

Dagnew, M., \& Danlena, M. (1995). Attrition rates among student nurses at the Gondar college of medical sciences. The Ethiopian Journal of Health Development, 9(1), 87-90.

Demetriou, C., \& Schmitz-Sciborski, A. (2011). Integration, motivation, strengths and optimism: Retention theories past, present and future. In R. Hayes (Ed.), Proceedings of the seventh national symposium on student retention, Charleston. (pp. 300-312). Norman, OK.

Fowler, M. (n. d.). Student retention problems in higher education in a developing country.

Glenda, C. (2017). Student retention in higher education, A shared issue. In J. C. Shin \& P. Teixeira (Eds.), Encyclopedia of International Higher Education Systems and Institutions., https://doi.org/10.1007/978-94-017-9553-1_314-1

Higher Education Relevance and Quality Agency, HERQA. (2008a). Hawassa university institutional quality audit report. HERQA.

Higher Education Relevance and Quality Agency, HERQA. (2008b). Mekele university institutional quality audit report. HERQA.

Higher Education Relevance and Quality Agency, HERQA. (2014). Wolaita Sodo university institutional quality audit report. HERQA.

Higher Education Relevance and Quality Agency, HERQA. (2017). Wolkite university institutional quality audit report. HERQA.

Jensen, U. (2011). Factors influencing student retention in higher education. In Pacific Policy Research Center (Ed), Summary of influential factors in degree attainment and persistence to career or further education for at-risk/high educational need students (pp,2-5). Kamehameha Schools-Research \& Evaluation Division, Pacific Policy Research Center.

Kassie, K. (2018). Gender difference in higher education in Ethiopia: A case of Addis Ababa University (AAU). African Review (Dar Es Salaam, Tanzania), 10(2), 157-172. https://doi.org/10.1080/09744053.2018.1485254

Kerby, M. B. (2015). Toward a new predictive model of student retention in higher education: An application of classical sociological theory. Journal of College Student Retention, 17(2), 138-161. https://doi.org/10.1177/1521025115578229

Lang, M. (2001). Student retention in higher education: Some conceptual and programmatic perspectives. Journal of College Student Retention, 3(3), 217-29. https://doi.org/10.2190/LORL-328M-4VVG-WKUB

Levitz, R., \& Noel, L. (2008). Student success, retention, and graduation: Definitions, theories, practices, patterns, and trends. The $R$ Journal, 9(2), 27-40.

Ministry of Education, MoE. (2015). Education Sector Development Programme, ESDP V (2015/16 - 2019/20). MoE.

Ministry of Education, MoE. (2017). Education statistics annual abstract. Addis Ababa: MoE. 
Ministry of Finance and Economic Development, MoFED.(2016). Growth and Transformation Plan II (GTP II) (2015/16-2019/20). MoFED.

Molla, T., \& Cuthbert, D. (2014). Qualitative inequality: Experiences of women in Ethiopian higher education. Gender and Education, 26(7), 759775. https://doi.org/10.1080/09540253.2014.970614

Negash, T. (2006). Education in Ethiopia: From crisis to the brink of collapse. Discussion paper 33. Nordiska Afrikainstitutet.

New Vision. (2019). National universities: Student drop-out rates alarming. New vision blog. Retrieved

from https://www.newvision.co.ug/new_vision/news/1502587/universities-student-drop-rates-alarming

Rowley, J. (2003). Retention: Rhetoric or realistic agendas for the future of higher education. International Journal of Educational Management, 17(6), 248-253. https://doi.org/10.1108/09513540310487578

Sewasew, D. T. (2014). Attrition causes among university students: The case of Gondar university, North West Ethiopia. Innovare Journal of Social Sciences, 2(2), 27-34.

Simpson, O. (2006). Predicting student success in open and distance learning. Open Learning, 21(2), 125-

138. https://doi.org/10.1080/02680510600713110

Thomas, L. \& Cooper, M. (Eds.). (2003). Improving completion rates among disadvantaged students. Trentham Books.

Tilahun, A. (2003). Assessment of student attrition at the Faculty of Science, Addis Ababa University. (Master's thesis). Available from etd.aau.edu.et

Tinto, V. (1975). Dropout from higher education: A theoretical synthesis of recent research. Review of Educational Research, 45(1), 89125. https://doi.org/10.3102/00346543045001089

Tinto, V. (1987). From theory to action: Exploring the institutional conditions for student retention. In J. C. Smart (Ed.), Higher education: Handbook of theory and research. University of Chicago Press.

Tinto, V. (1999). Taking retention seriously: Rethinking the first year of college. NACADA Journal, 19(2), 5-9. https://doi.org/10.12930/02719517-19.2.5

Tinto, V. (2004). Student retention and graduation : facing the truth, living with the consequences. Occasional paper 1. The Pell Institute for the Study of Opportunity in Higher Education.

Tinto, V. (2006). Enhancing student persistence: Lessons learned in the United States. Análise Psicológica, 1(24), 7-13.

Tinto, V. (2007). Research and practice of student retention: What next? Journal of College Student Retention, 8(1), 119. https://doi.org/10.2190/4YNU-4TMB-22DJ-AN4W

UNESCO. (1988). Ethiopia: Tertiary education and national development. UNESCO.

Weldegiorgis, T., \& Awel, Y. M. (2013). Determinants of student attrition at College of Business and Economics, Mekelle University: Econometric investigation. In Proceedings of the national symposium on establishing, enhancing \& sustaining quality practices in education. Wollega University.

World Bank. (2003). Higher education development for Ethiopia: Pursuing the vision. World Bank. 